\title{
BIOCHEMICAL POLYMORPHISM IN CHARR (SALVELINUS ALPINUS L.) FROM THREE CUMBRIAN LAKES
}

\author{
A. R. CHILD \\ Ministry of Agriculture, Fisheries and Food, Directorate of Fisheries Research, Fisheries \\ Laboratory, Pakefield Road, Lowestoft, Suffolk NR33 OHT, U.K.
}

Received 25.i.84

\section{SUMMARY}

\begin{abstract}
Blood sera from four populations of charr (Salvelinus alpinus L.) inhabiting three lakes in Cumbria were analysed for genetic polymorphisms. Evidence was obtained at the esterase locus supporting the genetic isolation of two temporally distinct spawning populations of charr in Windermere. Significant differences at the transferrin and esterase loci between the Coniston population of charr and the populations found in Ennerdale Water and Windermere were thought to be due to genetic drift following severe reduction in the effective population size in Coniston water.
\end{abstract}

\section{INTRODUCTION}

The Arctic charr (Salvilinus alpinus L.) has a circumpolar distribution in the northern hemisphere. The populations in the British Isles are confined to isolated lakes in Wales, Cumbria, Ireland and Scotland. Charr north of latitude $65^{\circ} \mathrm{N}$ are anadromous but this behaviour has been lost in southerly populations.

This paper describes an investigation of biochemical polymorphism of the isozyme products of two loci, serum transferrin and serum esterase, in charr populations from three Cumbrian lakes-Windermere, Ennerdale Water and Coniston Water (fig. 1).

Electrophoretic methods applied to tissue extracts have been employed by several workers in an attempt to clarify the "species complex" in Salvelinus alpinus and to investigate interrelationships between charr populations (Nyman, 1972; Henricson and Nyman, 1976; Child, 1977; Klemetsen and Grotnes, 1980). Electrophoretic analysis of serum proteins from charr revealed a polymorphic esterase with two codominant alleles (Nyman, 1965, 1967). A further polymorphism was described at the transferrin locus with two codominant alleles (Child, 1977). The frequencies of these codominant alleles can be used to investigate the gene pools of charr populations.

The particular problem associated with the Cumbrian charr is the presence of charr populations which differ in the season at which they spawn. The spring (February-March) spawning charr is probably unique to Cumbrian lakes and occurs in Coniston Water and Windermere. In the latter lake it is found with a population of autumn (November) spawning charr.

The biology of the Cumbrian charr has been extensively studied by Frost $(1955,1965,1978)$ and Kipling and Frost (1978). It can be briefly summarised as follows. The charr lay their eggs on stony grounds. Autumn spawners

This article is reproduced by permission of the Controller of Her Majesty's Stationery Office, who retains the copyright. 


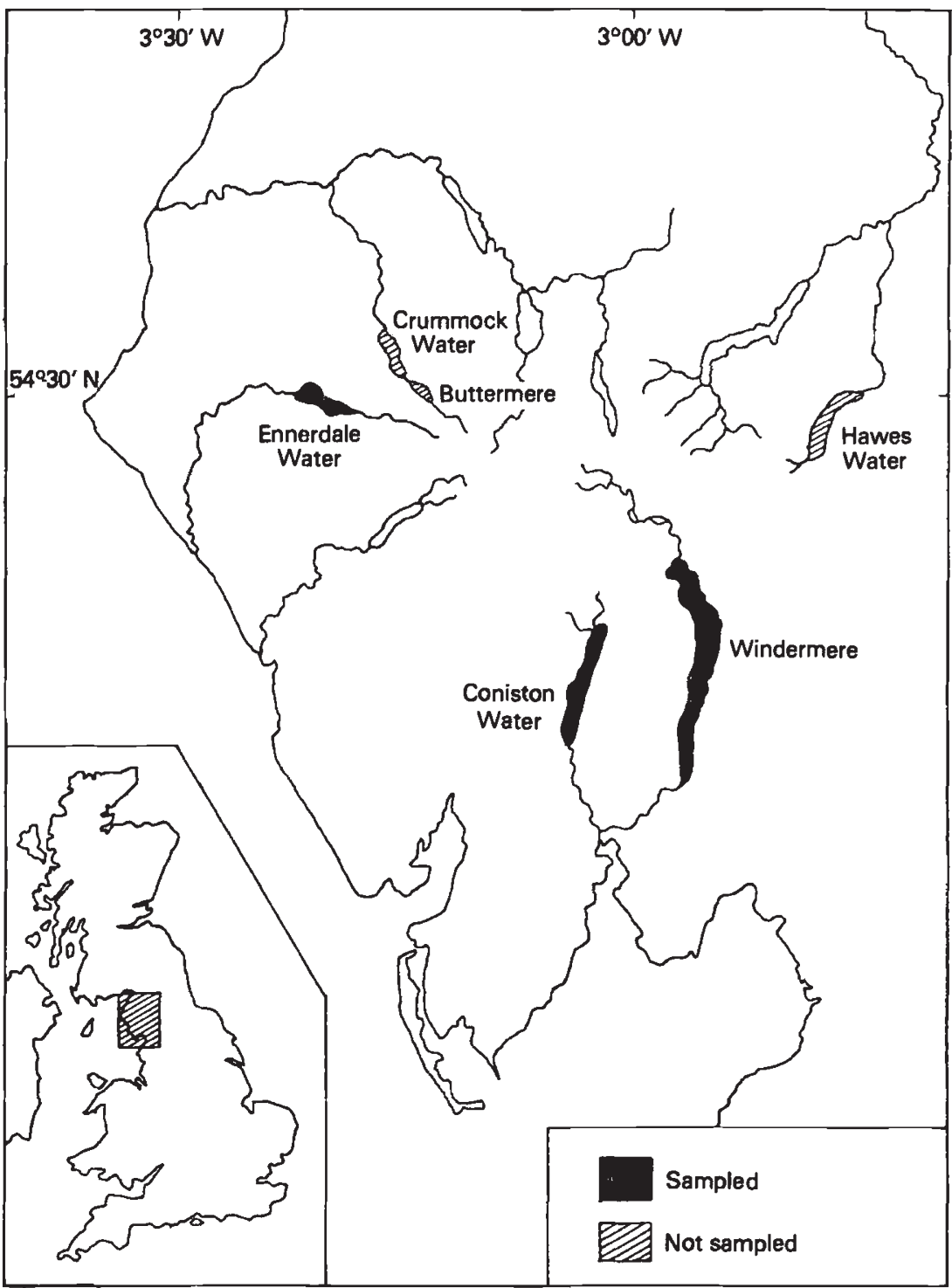

FIG. 1. Sketch map of Cumbria showing the lakes containing charr and those from which charr were sampled.

utilise the shallow water or the edge of the lake (1-3 m) and afferent streams, while the spring spawners lay their eggs in deep water $(15-20 \mathrm{~m})$. In Windermere the autumn spawners have average gill raker numbers of $13 \cdot 3$ (range 11-16) and the spring spawners 15.1 (range 13-17). Charr in Ennerdale Water spawn in autumn and have on average $15 \cdot 1$ (range 11-18) gill rakers. Coniston Water charr spawn in spring and have on average 14.9 (range 13-17) gill rakers (Frost, 1965). Breeding experiments carried out by Frost showed that there is no barrier to cross fertilisation between prematurely spawning spring charr and late autumn charr. 
In the wild state, the two Windermere populations appear to maintain reproductive isolation, and homing experiments show that the charr return to their natal grounds to spawn (Frost, 1965).

The analyses of serum protein polymorphisms presented in this paper test for genetic evidence for the separation of the autumn and spring spawning charr and investigate the genetic relationships between the charr of the other two lakes studied.

\section{MATERIALS AND METHODS}

The sites, time of collection and numbers sampled are shown in table 1. The locations of the Windermere sites are shown in fig. 2. Red Nab and Holbeck Point are recognised spawning sites, Rawlinson Nab is not (T. B. Bagenal, personal communication). All fish were in spawning condition when collected. The locations of the Windermere sites are shown in fig. 2 .

TABLE 1

Sites and numbers of spawning charr taken from Windermere, Ennerdale Water and Coniston Water

\begin{tabular}{llc}
\hline \multicolumn{1}{c}{ Site } & \multicolumn{1}{c}{ Date } & Number \\
\hline Windermere & & \\
Red Nab & 1975 November & 63 \\
Red Nab & 1976 November & 50 \\
Rawlinson Nab & 1976 November & 17 \\
Holbeck Point & 1976 February & 38 \\
Ennerdale Water & 1976 November & 7 \\
& 1978 November & 20 \\
Coniston Water & 1977 February & 15 \\
\hline
\end{tabular}

The method of collection, sampling and electrophoretic analysis are as described in Child (1977). Isozymes encoded by the serum esterase, transferrin, lactate dehydrogenase and glucose phosphate isomerase loci were identified. The observed numbers of phenotypes at the transferrin and esterase loci were analysed for genetic balance. Contingency chi-squared tests were carried out on each population.

\section{RESULtS}

Serum transferrin and serum esterase were both polymorphic with two codominant alleles at each locus described as Tfl and Tf2 and Es 1 and Es 2 respectively, in order of decreasing anodal mobility. Es 1 and Es2 correspond to the Est $F$ and EstS of Nyman (1972).

The samples collected in autumn from Windermere were tested at both loci for difference between sites (Red Nab and Rawlinson Nab, 1976), and between years at the same site (Red Nab, 1975 and 1976). Differences between sexes were tested for samples collected at Holbeck in the spring (Holbeck Point, 1976). No significant differences were found. Tests for genetic balance at the transferrin locus showed that the observed numbers 
252

A. R. CHILD

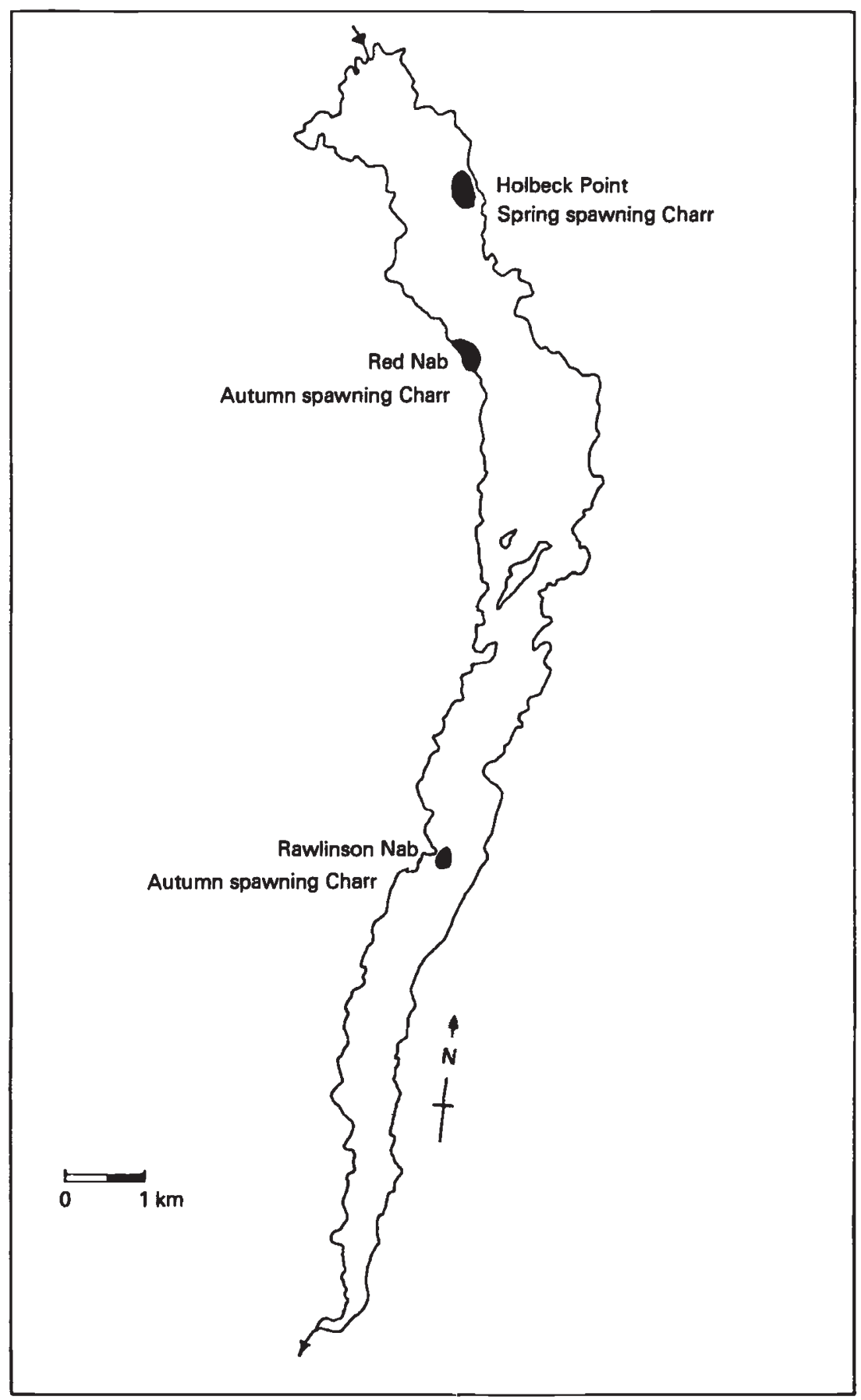

FIG. 2. Sketch map of Windermere showing charr sampling sites. 


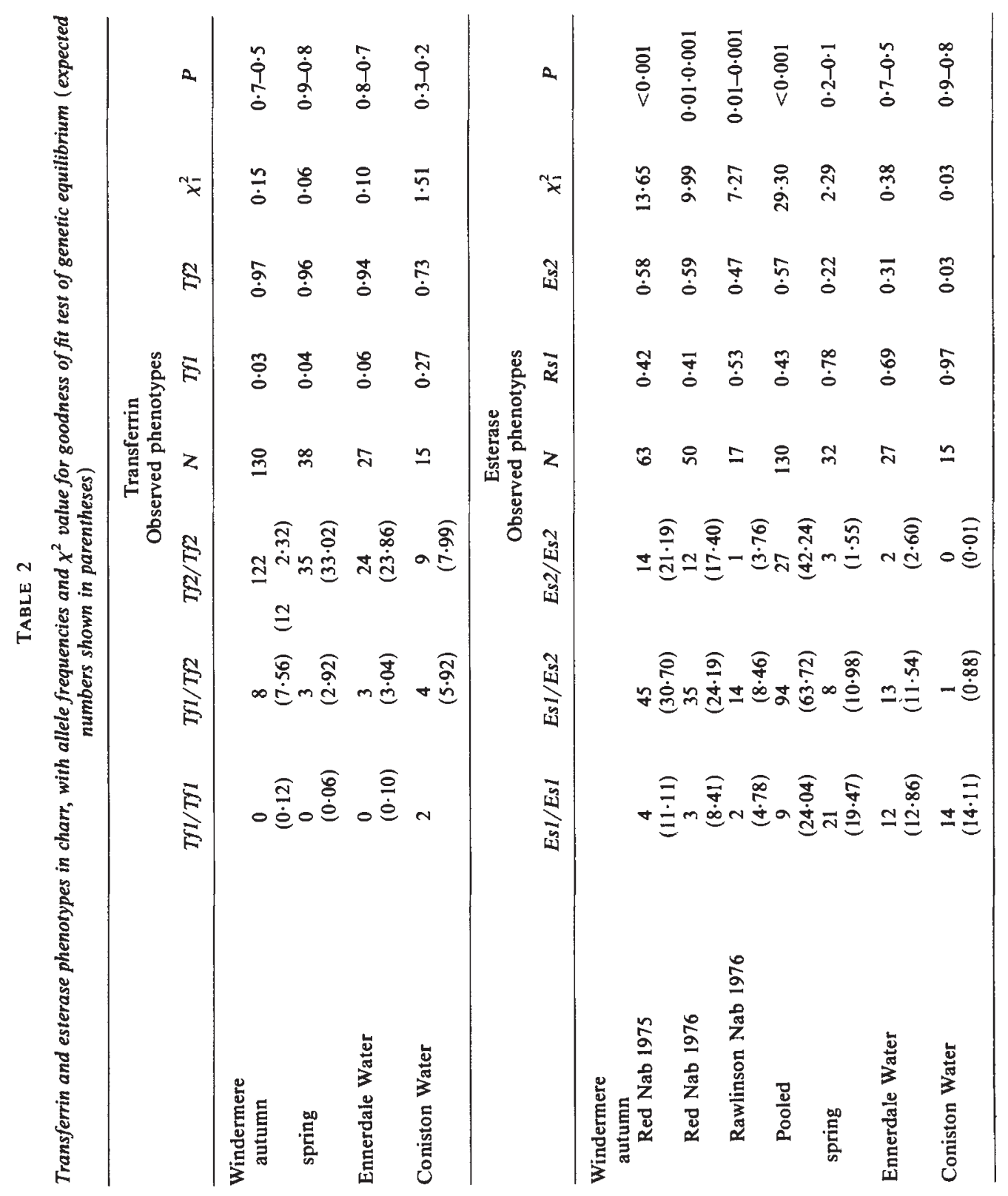


of phenotypes did not differ from the expected numbers (table 2). At the esterase locus there was no significant imbalance in charr from Windermere (spring), Ennerdale Water or Coniston Water. There was, however, consistent heterozygote excess in the autumn charr from Windermere with pooled samples having $\chi_{1}^{2}=29.30, P<0.001$. The contingency test (table 3 ) revealed significant differences between populations at both loci. Pairwise contingency tests show a significant difference between Coniston Water

TABLE 3

Contingency $\chi^{2}$ test for transferrin and esterase alleles in charr from Windermere (autumn and spring), Ennerdale Water and Coniston Water (expected values in parentheses)

\begin{tabular}{|c|c|c|c|c|c|}
\hline & \multicolumn{5}{|c|}{ Transferrin alleles } \\
\hline & $T f 1$ & $T f 2$ & $2 N$ & $x_{1}^{2}$ & $P$ \\
\hline \multicolumn{6}{|l|}{ Windermere } \\
\hline autumn & $\begin{array}{c}8 \\
(13 \cdot 6)\end{array}$ & $\begin{array}{l}252 \\
(246 \cdot 4)\end{array}$ & 260 & $2 \cdot 45$ & $0 \cdot 2-0 \cdot 1$ \\
\hline spring & $\begin{array}{l}3 \\
(3 \cdot 98)\end{array}$ & $\begin{array}{l}73 \\
(72 \cdot 02)\end{array}$ & 76 & $0 \cdot 26$ & $0 \cdot 7-0 \cdot 5$ \\
\hline Ennerdale Water & $\begin{array}{l}3 \\
(2 \cdot 83)\end{array}$ & $\begin{array}{l}51 \\
(51 \cdot 17)\end{array}$ & 54 & 0.01 & $0.95-0.9$ \\
\hline Coniston Water & $\begin{array}{l}8 \\
(1 \cdot 57)\end{array}$ & $\begin{array}{l}22 \\
(28 \cdot 43)\end{array}$ & 30 & $27 \cdot 75$ & $<0.001$ \\
\hline Total & 22 & 398 & 420 & & \\
\hline \multicolumn{6}{|c|}{ Contingency $\chi_{3}^{2}=30.47, P<0.001$} \\
\hline & \multicolumn{5}{|c|}{ Esterase alleles } \\
\hline & Esl & Es2 & $2 N$ & $\chi_{1}^{2}$ & $P$ \\
\hline \multicolumn{6}{|l|}{ Windermere } \\
\hline autumn & $\begin{array}{l}112 \\
(145 \cdot 3)\end{array}$ & $\begin{array}{l}148 \\
(114 \cdot 7)\end{array}$ & 260 & $17 \cdot 29$ & $<0.001$ \\
\hline spring & $\begin{array}{c}50 \\
(35 \cdot 8)\end{array}$ & $\begin{array}{l}14 \\
(28 \cdot 2)\end{array}$ & 64 & $12 \cdot 84$ & $>0.001$ \\
\hline Ennerdale Water & $\begin{array}{c}37 \\
(30 \cdot 2)\end{array}$ & $\begin{array}{c}17 \\
(23 \cdot 8)\end{array}$ & 54 & $3 \cdot 50$ & $0 \cdot 1-0 \cdot 05$ \\
\hline Coniston Water & $\begin{array}{l}29 \\
(16 \cdot 8)\end{array}$ & $\begin{array}{c}1 \\
(13 \cdot 2)\end{array}$ & 30 & $20 \cdot 24$ & $<0.001$ \\
\hline Total & 228 & 180 & 408 & & \\
\hline \multicolumn{6}{|c|}{ Contingency $\chi_{3}^{2}=53.87, P<0.001$} \\
\hline
\end{tabular}

and autumn Windermere populations $\left(\chi_{1}^{2}=28 \cdot 712, P<0.001\right)$ at the transferrin locus. Significant differences at the esterase locus occur between autumn Windermere charr and spring Windermere charr $\left(\chi_{1}^{2}=25 \cdot 235, P<\right.$ $0.001)$, Ennerdale Water charr $\left(\chi_{1}^{2}=11.607, P<0.001\right)$ and Coniston Water charr $\left(\chi_{1}^{2}=30.921, P<0.001\right)$. There is also a significant difference between Ennerdale Water and Coniston Water $\left(\chi_{1}^{2}=9.076,0.01>P>0.001\right)$ and spring Windermere charr and Coniston $\left(\chi_{1}^{2}=5 \cdot 236,0.05>P>0.02\right)$. 
Analysis of lactate dehydrogenase and glucose phosphate isomerase agreed with the description of these loci in Welsh charr (Child, 1977).

\section{Discussion}

The significant difference between the autumn and spring spawning charr from Windermere at the serum esterase locus supports the hypothesis of genetic isolation of these populations. The heterozygote excess of this locus in the autumn spawning charr may indicate selection for this genotype but the reasons for this are not clear.

Heterozygote excess in autumn Windermere charr has been noted by Nyman (pers. comm.). Ferguson (1981) presented observed and expected phenotype numbers for esterase in a small sample (19) of autumn Windermere charr and although the $G$ statistic did not signify a significant excess of the heterozygotes, the observed numbers were larger than the expected numbers.

The possibility that the heterozygote excess was due to sampling error can be dismissed because it was consistently found not only in samples from the same area in different years but also in samples from different areas in the same year. It is unlikely that the esterase phenotypes were mistyped since the esterase locus has been reported as a simple two allele polymorphism by different authors using different buffer systems and gel media.

Correlation between esterase genotypes and temperature have been found for various fish species; Anoplarchus purpurescens (Johnson, 1977) and Catastomus clarkii (Koehn and Rasmussen, 1967) are two examples. In both species, frequency of esterase alleles has been related to a cline in temperature. The fast esterase allele in Scandinavian lake populations of charr have been shown to fit a north-south cline (Nyman, 1972). Nyman and Shaw (1971) demonstrated that the kinetics of charr esterase differed such that the fast esterase was more active at higher temperatures. It is possible that the autumn spawned charr fry experience a wide range of temperatures in the shallow water where they hatch and, as a consequence, the heterozygote may be better adapted to these conditions, having two isozymes with kinetics associated with "high" and "low" temperatures. The charr from Ennerdale Water do not show this heterozygote excess, but their eggs are laid in a deep pool in the afferent stream (River Liza) which may be less influenced by temperature. This explanation is not supported by the comment of E. D. Le Cren (pers. comm.) who suggests that greater temperature fluctuations may occur in the river. Windermere charr are known to spawn in the River Brathay: it would be advantageous to examine these charr for heterozygote excess at the esterase locus.

The origins of the spring and autumn charr are of particular interest. Regan (1911) suggested that two populations differing in spawning time may have colonised the Cumbrian lakes after the last glaciation. The differences in spawning ecology (i.e., deep and shallow water) and spawning times may have been sufficiently large to maintain reproductive isolation. Frost (1965) suggested that the Cumbrian charr had an extended spawning period from November to March. Disruptive selection in which pressures favoured early or late spawning charr may have eliminated intermediate spawning individuals. One suggested selective factor may have been 
daylength. Both autumn and spring spawning occur when the daylength is $8.5 \mathrm{~h}$. This situation does not, however, prevail in all Cumbrian lakes, the charr of Haweswater, Crummock Water and Buttermere spawn in January. They may represent populations upon which disruptive selection has not acted.

The significant differences between the Coniston Water population and the other three populations may have been due to sampling error since there were only 15 individuals in the Coniston sample; however, examination of the 95 per cent confidence limits for the Coniston sample shows that there is no overlap between the gene frequency estimates for Coniston charr and the other charr samples.

There is circumstantial evidence from historical reports that the population of charr in Coniston Water was considerably reduced in size, if not eliminated and re-introduced. A spring-spawning population in Coniston was mentioned in the accounts of Sir David Fleming in 1681-84 (Frost, 1965). Spring spawners were recorded in Coniston Water in 1835 (Regan, 1911); however, a report to Parliament in 1878 stated that "in Coniston, the fish have been poisoned by the mines" (Buckland, 1880). This suggests that the population of spring spawning charr may have been either reduced to a very small effective breeding size of re-introduced after extinction. In either of these circumstances, reduced population size could give rise to a population bottleneck and allow significant changes in the gene frequencies due to genetic drift.

Evidence reported in this present paper lends genetic support to differences between the two populations in Windermere and also suggest an explanation for the differences in allele frequencies found in Coniston Water charr.

Further information could possibly be gained from the examination of more enzyme systems. However, a study by Ferguson $(1980,1981)$ reports only one polymorphic locus, esterase, in 26 loci tested in 205 individual charr.

Acknowledgements. This work could not have been carried out without the considerable assistance of Dr T. Bagenal and the staff at the Freshwater Biological Association Laboratory, Ferry House, Windermere, and I thank them for their support. I am also indebted to the late $\mathrm{Dr}$ W. E. Frost for the wealth of information provided on the biology of Cumbrian charr.

\section{REFEFERENCES}

BUCKLAND, F. 1880. Natural History of British Fishes. Unwin Bros., Chilworth and London. CHILD, A. R. 1977. Biochemical polymorphism in char (Salvelinus alpinus L.) from Llynnau Peris, Padarn, Cwellyn and Bodlyn. Heredity, 38, 359-365.

FERGUSON, A. 1980. Electrophoretic analysis of tissue proteins of Irish charr. Proc. First ISACF Workshop on Arctic Char, 1980. Drottningholm, Sweden. Inf. Ser. int. Soc. Arct. Char Fanatics, No. 1, 12-14.

FERGUSON, A. 1981. Systematics of Irish charr as indicated by electrophoresis analysis of tissue proteins. Biochem. Syst., $9(2 / 3), 225-232$.

FROST, W. E. 1955. An historical account of the char in Windermere. Salm. Trout Mag., 143, 15-24.

FROST, W. E. 1965. Breeding habits of Windermere charr, Salvelinus willughbii (Günther), and their bearing on speciation of these fish. Proc. R. Soc. (B), 163, 232-284.

FROST, W. E. 1978. The scales of the charr (Salvelinus willughbii Günther), in Windermere, and their use for determination of age and growth. J. Cons. int. Explor. Mer, 38, 208-215. 
HENRICSON, J. AND NYMAN, L. 1976. The ecological and genetical segregation of two sympatric species of dwarf char (Salvelinus alpinus (L.) Species Complex). Rep. Inst. Freshwat. Res., Drottningholm, 55, 15-37.

JOHNSON, M. S. 1977. Association of allozymes and temperature in the crested blenny (Anoplarchus purpurescens). Mar. Biol., 41, 147-152.

KIPLING, C. AND FROST, w. E. 1978. The weight-length relationship of charr (Salvelinus willughbii Günther) in Windermere. J. Cons. int. Explor. Mer, 38, 216-219.

KLEMETSEN, A. AND GROTNES, P. E. 1980. Coexistence and immigration of two sympatric arctic charr. In Balon, E. K. (ed.) Charrs, Salmonid Fishes of the Genus Salvelinus. Dr W. Junk, The Hague, The Netherlands.

KOEHN, R. K. AND RASMUSSEN, D. 1. 1967. Polymorphic and monomorphic esterase heterogeneity in catastomid fish populations. Biochem. Genet., 1, 131-144.

NYMAN, L. 1965. Variation of proteins in hybrids and parental species of fish. Rep. Swed. Salm. Res. Inst. LFI Medd., 13, 1-6.

NYMAN, L. 1967. Protein variations in Salmonidae. Rep. Inst. Freshwat. Res. Drottningholm, 47, 5-38.

NYMAN, L. 1972. A new approach to the taxonomy of the "Salvelinus alpinus species complex". Rep. Inst. Freshwat. Res. Drottningholm, 52, 103-131.

NYMAN, L. AND SHAW, D. H. 1971. Molecular weight heterogeneity of serum esterase in four species of salmonid fish. Comp. Biochem. Physiol., 40B, 563-566.

REGAN, C. T. 1911. The Freshwater Fishes of the British Isles. Methuen, London. 